\title{
Reading the Bible in the African context: Assessing Africa's love affair with prosperity Gospel
}

\author{
Cezula, Ntozakhe \\ Stellenbosch University \\ cezulans@sun.ac.za
}

\begin{abstract}
The aim of this article is to examine Bible reading in the African context and the willingness and enthusiasm to embrace prosperity gospel in Africa. To achieve this objective, a discussion on the developments in biblical interpretation in Africa will first be presented. This will be done by examining three historical periods: colonial, independence and democratisation periods. This will be followed by an outline of migrations that have taken place from traditional religions to different versions of Christianity in different times in Africa. These migrations will be examined in connection with Bible translation. The relationship between prosperity gospel and African people in Africa will be discussed by considering the tools prosperity gospel uses to appeal to African people, namely the religio-cultural and socio-economic factors. The article will then provide its assessment of contextual reading in the prosperity gospel and a conclusion will follow.
\end{abstract}

Keywords:

Bible Reading; Bible Translation; Contextual Reading; Pentecostalism; Prosperity Gospel

\section{Introduction}

The aim of this article is to examine two distinct but related phenomena, namely; Bible reading in the African context on the one hand and the willingness and enthusiasm to embrace prosperity gospel in Africa on the other. By reading the Bible, the article refers to at least three processes: looking at written words and comprehending their meaning, interpreting the meaning in relation to one's life experiences, and endorsing and concretising the interpretation in action. To achieve its objective therefore, the article will first present a discussion on the developments in biblical 
interpretation in Africa. This will be done by looking at three historical periods: colonial, independence and democratisation periods. An outline of migrations that have taken place from traditional religions to different versions of Christianity in different times in Africa will be presented. It will then examine the relationship between prosperity gospel and African people in Africa by considering the tools prosperity gospel uses to appeal to African people, namely the religio-cultural and socio-economic factors. It is of importance to indicate that although prosperity gospel originated in North America, there will be no comparison of the two contexts. The interest of the article is Bible reading in Africa, why prosperity gospel is popular in Africa and the effects thereof. Such a study needs its own space and time. The article will then provide its assessment of contextual reading in the prosperity gospel and finish with a conclusion.

\section{Bible reading in Africa}

In this article "reading the Bible" entails at least three processes: to look at written words and comprehend their meaning (scan), interpret their meaning (explicate) and endorse and concretise the interpretation in actions (practice). Reading the Bible in the African context is not a monolithic phenomenon but rather a polylithic one. Justin Ukpong expresses reading the Bible in the African context as a diverse and complex challenging process (2001:152). This article declares that both the natures of "the Bible" and "the African context" contribute to the complexity of Bible reading in Africa. Ukpong states that because of its ambivalence, the Bible can be put to different uses. "One good example here is the use of the Exodus story in South Africa by the Afrikaners to legitimate apartheid early last century, and by Black theologians since the middle of that century to fight apartheid, each side using a different ideological position for its reading" (Ukpong 2001:149). He argues that the African context is a "social, economic, political and religious context that is complex, multifaceted, and often vexed" (Ukpong 2001:152). Also, when one uses the phrase "the context", it should be remembered that Africa has different historical periods, different geographical locales, different cultural groups, etc. Drawing a picture of the nature of reading the Bible in Africa cannot be exhausted but what has been said thus far should hint to at least a vivid idea as to how complex it is. Against this background, the article shall examine Bible reading in 
the African context and later assess Africa's love affair with the prosperity gospel.

\section{a. The colonial period}

Bible reading in Africa can be traced back to the times of Augustine of Hippo during the Middle Ages and beyond (cf. Acts 26:27-28). However, for the purpose of this paper, the late nineteenth century until the present will be the focus. This is the period of colonisation (late nineteenth century to the first half of the $20^{\text {th }}$ century), independence (from the second half of the $20^{\text {th }}$ century) and democratisation of Africa (from the last quarter of the twentieth century). The winds that blew during these periods did not leave Bible reading untouched. During the colonial period, Africa was approached by both political and commercial interests as well as mission agencies from Christian Europe (Holter 2001:70). According to Knut Holter, at the end of the colonial period Africa produced not only a large number of independent states but also of independent churches as well. In terms of biblical interpretation, this period is characterised by an asymmetry with regard to institutionalised, interpretive power. In spite of the rapid growth of the church in Africa, the Europeans still tended to be in control of the interpretation of the Bible in the church and academia. The exportation of fully developed dogmatic systems by European mainline congregations for Bible interpretation in Africa's fast-growing churches ensured the control of the church. In the academia, the European interpretive models dominated the training in the not-so-fast growing theological training institutions. This resulted in a particular reflection of the relationship of Africa and Europe in the colonial Bible interpretation. The interpretation presents African religion and culture as inferior to the European ones and reflects the servitude of Africa to Europe (Holter 2008:70-73).

\section{b. Post-colonial and democratisation periods}

During the period after colonisation (post-colonial period), African scholars also became highly active characters in the drama of biblical interpretation with the result that the inferiority and servitude of Africa to Europe was challenged (Holter 2008:73-76). Again, Holter's (2008) assessment of the situation informs this subsection. He states that there emerged a remarkable growth of academic biblical studies produced in Africa by Africans and African academic institutions. This has been largely 
a period of emphasising and exemplifying how the African context of the interpreter can be accommodated by biblical interpretation in Africa. Consequently, this is also an interpretation that implicitly challenged the traditional European ownership of academic biblical interpretation. Nevertheless, most African biblical scholars continued to receive their training in Western contexts (cf. Nyende 2007:61; Bosman 2014:6). Colonial tendencies still manifested in both academic and ecclesial levels. Post-colonial African biblical interpretation reflected a context where the asymmetric distribution of economic power and scholarly hegemony continued to exist. African biblical scholarship was only able to challenge to a limited extent the traditional European ownership of academic biblical interpretation (Holter 2009:76). For Ukpong, Bible reading in Africa is composed of two currents of academic reading, one following the Western pattern while the other the African pattern of linking the text with the African context (Ukpong 2000:4; cf. Masenya \& Ramantswana 2012). The conflict between these two currents is a methodological one: whether biblical interpretation should emphasise the context of the text and its author (Western) ${ }^{1}$ or the context of the reader (African). These periods should not be viewed as compartments but overlapping and fluid time periods.

The state of affairs as far as Bible reading is concerned continued as portrayed in the previous subsection. Of importance here is the unfolding of the socio-historical circumstances. The progression from the colonial era to the democratisation of Africa is carefully captured by Mugambi. $\mathrm{He}$ discloses that "during the 1960s most of African nations attained sovereignty. There was much euphoria as well as high expectations especially amongst the younger generation. During the 1970s, that optimism faded into disillusionment while the 1980s were characterised by cries of despair all over the continent" (Mugambi 2003:162). ${ }^{2}$ This historical context is also important to explain some of the phenomena in the religious sector.

1 It is important to take note of Holter's assertion that: "Historical-critical methodology as we know it from Old Testament studies cannot escape the impression of being a typically western approach, an exponent of a western epistemology and hermeneutics of the eighteenth to twentieth centuries" (2011:378).

2 The situation in South Africa is similar even after twenty years of freedom as an SA Reconciliation Barometer Survey 2013 Report indicates: "The top three institutions as far as citizen confidence in 2013 is concerned, are religious institutions (67\%), the Public 


\section{c. Institutional and popular readings}

So far, the discussion has focused on the institutional reading of the Bible in theological institutions. ${ }^{3}$ Institutional reading is engaged in scientific activity and generation of knowledge (Ukpong 2001:160). Describing their calling as institutional readers, Ukpong says:

We are not mere readers of the Bible, but its professional, critical readers... As professional critical readers of the Bible, we exegetes are ... 'public intellectuals'. This distinguishes us from private readers of the Bible for we read the Bible not just for ourselves but also for public consumption (2001:152).

In a similar vein, Bosman (2014) asserts that:

The interpretation of the Old Testament in Africa seldom strives to understand the biblical text for its own sake or due to idle scholarly curiosity. In most instances African Old Testament scholarship is explicitly contextual and even confessional in nature and thus the ecclesial contexts are important for the comprehension of biblical scholarship on the African continent (2014:260).

Thus, Bible reading is also a popular occupation. Popular reading refers to Bible interpretation taking place in "churches, homes and open spaces (Nyende 2007:59) and schools (Holter 2008:210). This kind of reading involves unscientific activity and consumption of knowledge (Ukpong 2001:160). "At the level of popular biblical interpretation, some of the interpretative subjects are professional interpreters such as evangelists and pastors, but the large majority is made up of ordinary readers of the Bible; lay Christians who interpret the Bible in homes, schools and churches" (Holter 2008:210). Even at this level of Bible reading, the duality we perceived at institutional level can be detected. In the epilogue of his book ${ }^{5}$, Jurie le Roux (1993) states that the immanent approach, which was the

Protector (64.4\%) and the Constitutional Court (59.3\%). The three institutions with the lowest ratings are political parties (46.2\%), the police $(47.9 \%)$ and local government (48.6\%) (2013:19).”

3 In this category, Nyende includes universities' Religious Studies Departments and Faculties of Theology.

4 By open spaces, he refers to places like streets, markets, fields etc.

5 A Story of Two Ways: Thirty Years of Old Testament Scholarship in South Africa. 
dominant method of interpretation, was conveyed to theological students who used it in their ministry. He asserts that "it stepped beyond the narrow boundaries of the university to become part and parcel of the clergyman's ministry" (Le Roux 1993:351-352). On the other hand, Holter (2008:210) tells of Africanising strategies of popular biblical interpretation expressed through a broad spectrum of verbal and non-verbal genres. ${ }^{6}$ This reflects the two currents in the popular reading of the Bible as well, namely, the Westernising tendency on the one hand and the Africanising tendency on the other. To conclude this discussion, the article describes Bible reading in Africa as comprising basically and broadly of these parallel reading strategies. Let us now focus on the churches since they constitute some of the significant terrains of popular reading of the Bible. Specifically, we will examine membership migrations that have taken place among the different churches in Africa and are also related to Bible reading.

\section{Ecclesial migrations since the colonial era in Africa}

African people are by nature religious people. Before the encounter with colonialism, the article supposes that one would not easily find an atheist because of the holistic nature of the traditional African worldview. Since the colonial encounter, African people have migrated in numbers from their African Traditional Religion(s) to Christian missional churches and later to African Initiated Churches. ${ }^{7}$ This signals an intense longing and search for spiritual gratification. A history of the Christian religion in Africa from the colonial period is characterised in Graham Duncan and Ogbu U. Kalu's (2005) description of what they call bakuzufu. ${ }^{8}$

At several points in time, a movement would flare up as certain elements in the gospel, either its charismatic/pneumatic resource or its ethical imperative, would be emphasized enough to compel a new expression of its spirituality and structure. There would be a

6 Verbal genres include sermons, Bible studies, hymns, prayers and personal testimonies.

7 There were other foreign religions like Islam and other minority religions that Africans migrated to but this article focuses on the reading of the Christian Bible and Christian churches.

8 "Bakuzufu is the Luganda word for being re-awakened, or renewed or even resurrected; it is a very apt description for the English word 'revival'" (Duncan \& Kalu 2005:278). Luganda is one of the indigenous languages of Uganda. 
great excitement and popular interest beyond what may have been witnessed in years... A revival is not the mere appearance of a new version of Christianity but one that elicits massive attention and acceptance; it brings a new life to an old religion... At all times, revivals are the responses to the character of Christian living and message at certain times, in certain contexts, and may reflect the impact of external secular forces as people seek answers from the religious sphere (2005:278-279).

As will be indicated below, such moments have been experienced in Christianity in Africa. According to Mugambi (2005), "there is no doubt that the appeal of the Christian faith among many African converts was genuine and profound". In Jesus Christ, they found new hope to which they clung in the face of great challenges which would otherwise have broken their lives (2005:517). Nevertheless,

the baptized convert was considered to have been 'washed' of all aspects of the old existence, and was therefore expected to abandon the traditional customs of his community. It has been noted, however, that this missionary expectation was not fully realized because African Christians continued to hold some of the traditional ideas although they would not publicly participate in traditional ritual (2005:540-541).

With the advent of Bible translation, the church grew tremendously in Africa. According to Aloo O Mojola (2014) the spread of the church in Africa is inextricably connected to the translation of the Bible into the local tongues (cf. also Bosman 2014:256-257). "Once the Bible is in a vernacular, it becomes the property of that people. It becomes a Yoruba Bible... a Zulu Bible..." (Philip Jenkins, cited in Bosman 2014:256). Mojola avers that the translation of the Bible into the vernacular languages provided the fuel and rationale for the proliferation of the African Initiated Churches (AICs). $\mathrm{He}$ argues that as long as the Bible remained in the hands of the missionaries, it was possible for the missionaries to retain their control and authority in matters of faith and practice, at least in their sphere or domain of church influence. This was changed by the translation of the Bible into vernacular which provided a basis for checking the sources and the missionary message using the vernacular scriptures as a point of reference (Mojola 2014:1). The 
African Instituted Churches (AICs) thus arose as an affirmation of the emerging indigenous readings and interpretations of the Bible and of the Christian faith and the appropriation and inculturation of these. Their emergence was also widely viewed as a reaction to the entrenchment of missionary readings and practices, as well as authority and control in the mission-dominated churches (Mojola 2014:2). To satisfactorily grasp the role of Bible translation in the spread of the church, it might be beneficial to appreciate Mojola's description of the situation in the following words:

The new readers empowered to read the Bible for themselves in their own languages felt equipped to challenge and question missionary readings and interpretations of the sacred text in their own languages. They too could hear God speaking in their own languages. As authorities and masters of their own tongues, they could justifiably argue that the missionary could in no way claim to understand their language better than they themselves. This development inevitably led to confrontations and disputations which eventually led to "schisms and renewal", resulting in the then socalled African independent churches and now commonly referred to as the African initiated churches (Mojola 2014:1).

The earliest AICs to emerge were the so-called Ethiopian churches. However, they emerged as political and administrative reactions to mission-founded churches not necessarily theological reactions and therefore were similar to the European mission churches from which they broke away (Anderson 2001:15). They were African-led churches following "mainline" churches in liturgy, doctrine and church organisation (Anderson 2001:54). Anderson (2001) estimates that approximately two decades after the Ethiopian churches were started, another category of AICs emerged, namely, Zionist churches. He describes this group as "the largest and most significant grouping of the AICs". Differences in belief systems, liturgy and prophetic and healing systems between the Zionist churches and the missional churches are considerable (Anderson 2001:17). Because of occupying the middle ground in an increasingly polarised society and not offering radical alternatives, the Ethiopian churches declined from the second half of the twentieth century and were outshined by the other AIC categories (Anderson 2001:16). In 1991, possibly $8 \%$ of the African population belonged to Ethiopian churches compared to $32 \%$ for Zionists and Apostolics (Anderson 2001:59). The 
Zionist churches emphasise "the working of the power of the Spirit in the church" (Anderson 2001:16). They are said to emerge from mainline churches by recovering the pneumatic resources of the translated Bible and by deploying traditional symbols (Duncan \& Kalu (2005:282).The influence of the Holy Spirit and of divine healing was a radical shift from the missional churches. In fact, by presenting healing as an integral element of Christian salvation, building on indigenous worldview of causality (Asamoah-Gyadu 2012:169), these churches challenged the half-Christian who went to church respectably but then in secret and with guilty feelings went off to the diviner to seek the cause of sickness and the way of healing (AF Walls cited in Asamoah-Gyadu 2012:169). The biggest distinguishing feature is the almost universal use of uniforms for members: white robes with sashes and in some cases military-like khaki (Anderson 2001:18). Their unique contribution towards understanding Christianity in Africa is their adaptation to and addressing the popular African worldview more substantially than other types of churches do (Anderson 2001:18). While differing fundamentally from western Pentecostalism, they too emphasise the centrality of the Holy Spirit in faith and practice and therefore can be termed "African Pentecostal". This article does not use this term for the Zionist churches to avoid confusion with the Pentecostal churches which will be discussed below.

The third and the last category of AICs to emerge are the so-called Pentecostal or Charismatic churches. "North American in origin, the movement has had striking success in parts of Europe, Africa, and Latin America" (Robbins 2004:122). Like the Zionist churches, they emphasise the power and the gifts of the Holy Spirit. Summarising Anderson's insights, Ngong remarks that AICs offer solutions seemingly more powerful than those offered by either traditional means or Western Christianity, and they claim in the name of Christ deliverance from adversity. In fact, unlike Western theology that is highly theoretical the theology of the AICs is practical theology (Ngong 2009:13). For the purposes of this paper, this last category will be referred to as Pentecostal/Charismatic churches (PCCs) in distinction from Zionist churches for which the designation AIC will be reserved. PCCs vary in size from small independent house churches to rapidly growing and large organisations (Anderson 2001:19). Gladys Ganiel's (2006) observation is that Pentecostal/charismatic churches have 
grown while mainline churches have become less prominent in the public sphere (2006:558). Furthermore, the growth of these churches since the 1980s indicates that a significant number of their members come from missional churches and Zionist churches (Anderson 2001:19). AsamoahGyadu (2005:388) asserts that one of the most significant developments in African Christianity since the middle of the twentieth century is the rise, growth and impact of Pentecostalism. "In Johannesburg alone, there are well over 100 Nigerian founded new Pentecostal churches existing in March 2007" (Ukah 2007:12). An important remark about PCCs is that "There is a western, especially North American, Pentecostal influence in many of these churches both in liturgy and in leadership patterns, and North American 'prosperity' preachers are sometimes promoted" (Anderson 2001:19). It is this prosperity element that is the fundamental interest of this paper. The whole discussion thus far has been an attempt to introduce a discussion on prosperity gospel.

\section{Prosperity Gospel in Africa}

Birgit Meyer reveals that what is distinctly new about Pentecostal/ Charismatic Churches is their propagation of the Prosperity Gospel (sic) and their strong global inclination (Meyer 2004:453). This article is interested in the prosperity gospel strand of Pentecostalism and in investigating what could be the attraction to this gospel in Africa. The article reasons that the factors that create advantageous conditions for the prosperity gospel are both religious and socio-economic. Before we investigate what could be the causes of the growth of prosperity gospel in Africa, let us outline what prosperity gospel entails.

Prosperity gospel is not equal to Pentecostalism but a version or segment of Pentecostalism (Gbote 2013:54). Ukah (2007) describes prosperity gospel as a teaching of what he calls the new Pentecostals who espouse specific doctrines that mark them out among other groups of Christians. He asserts that they believe they constitute a special people of God who alone are saved and the rest of humanity is doomed to perdition. Theologically, a person is saved who is "born again" and is regenerated or sanctified by an inward feeling of holiness. Sanctification purifies a believer from sin and all forms of pollution. Of special importance is the teaching on the baptism of the Holy Spirit and external manifestation of speaking in tongues. This is 
both a spiritual and social marker, setting members apart as God's elected people. This new message promised individuals a comprehensive solution to all their worries on condition that they become born again and give generously to the religious leader in exchange for material and spiritual blessings in the form of healing, wealth, abundant life, success and earthly promotion (Ukah 2007:12). Donations to Christian ministries will always increase one's material wealth (Gbote 2013:54). With that background, let us now proceed to investigate what could be possible reasons for the attention that prosperity gospel seems to enjoy in Africa. This article considers the proliferation of prosperity gospel in Africa a result of a combination of two factors. The first one is Pentecostalism which taps into African religio-cultural conditions. As it has been indicated above, in Africa, Pentecostalism is the most successful of the three categories of AICs discussed above. The second one is the promise of material abundance which exploits the African socio-economic conditions.

\section{a. Religio-cultural factors}

The first aspect oflife that we shall explore is the African worldview. Although talk of African worldview might conjure up images of a homogenous African community, African cultures are heterogeneous but do share some commonalities. The holistic nature is a shared attribute and all aspects of life and universe are perceived as analytically indistinct because they exhibit an intrinsic unity, that is, an interconnected, interdependent and interrelated whole (Kimilike 2006:1). According to Ngong (2009:3),

In this context salvation means averting situations that diminish human material well-being... People offer prayers and sacrifices to the ancestors, to God or the gods, in order to obtain the power that may enhance human material well-being. And this material wellbeing in the form of enjoyment of long life, health, wealth, children, that is, possession and prosperity that engender happiness in this life, is the crucial denominator in ATRs.

Asamoah-Gyadu argues that by taking the African worldview seriously, Pentecostal/Charismatic. ${ }^{9}$ Christianity has proved a more credible alternative to existing mission churches whose theology has proved a bit

9 This is how he refers to prosperity gospel. 
too distant from the aspirations of the people. Pentecostals draw attention to the fact that the gospel is about restoration, so it is expected that the transformation of the personality would be manifest in personal health, well-being, and care; in short salvation is holistic and it includes spiritual as well as physical abundance (Asamoah-Gyadu 2005:408).

Clifton Clarke (2013) reveals another dimension of the African worldview when he bemoans the failure of some scholars of the Pan African Theological School to make an impact on Africans due to their use of the Enlightenment tradition in Scripture. He avers that:

Enlightenment hermeneutical lens proved ineffective in an African context primarily because it emphasized textuality and not orality. First, African Pentecostals are acutely aware of the dislocation that occurs between the text and the context. When African people read the Bible, a "dislocation" occurs and emphasis is not placed on the text's meaning in itself but rather on the meaning the text has for the people reading it. The enlargement of the text, which is a prominent practice within African Pentecostal hermeneutics, particularly in their preaching, allows them to connect the written text to the deep recesses of African oral consciousness. This multidimensional approach to biblical hermeneutics allows the written text to make deep connections with the African "spirit world" and oral tradition (Clarke 2013:174).

Another important element of the African worldview is the belief in the existence of spirits. David Adamo states that "spirits, according to African belief are 'apparitional entities', which belong to different categories of beings than the divinities... Belief in these spirits permeates the life of Africans and should be taken seriously" (Adamo 2011:4). At this juncture it is important to note Margaret J Field (1940) saying: "Though it is not difficult by warfare, foreign administration, modern industry and other means, to smash up an ancient religious organisation, the ideas which sustained it are not easily destroyed. They are only disbanded, vagrant and unattached. But given sufficient sense of need, they will mobilise again" (1940:149). Meyer asserts that Pentecostal/Charismatic Churches stress the importance of the Holy Spirit above biblical doctrines and provide room for prophetism, dreams and visions, speaking in tongues, prayer healing, and deliverance from evil spirits (2004:453). The significance of deliverance 
from evil spirits is made clear in Jele Manganyi and Johan Buitendag (2013) when they argue that “... To the traditional African there is no coincidence or accident. Nothing happens by chance". At this point they quote Simon Maimela who mentions that the traditional African lives his or her life through the manipulation of certain supernatural forces or spirits. These forces and spirits are also manipulated by the witches and sorcerers with evil intent or by medicine men and women to arrest and cure illness (2013:11). While these statements refer to the "traditional African", the truth is, even some of those who perceive themselves as modern Africans believe in evil spirits and witchcraft. This is reflected in a statement by Duncan and Kalu (2005) that "while the Xhosa lost the struggle to retain their political and socio-economic independence, 'the colonization of consciousness' itself was never complete, even among the Western educated black elite" (2005:279). Deliverance from evil spirits therefore becomes an attraction to a wide spectrum of African people. Some might not necessarily leave their mainline churches but will pay occasional visits to these churches for deliverance from evil spirits. As Mugambi (2005) indicates, that there was "a life of double standards among African Converts" (2005:519). They are even prepared to make offerings of large sums of money which they would not offer in their respective churches. Ukah (2007) notices that because of the proliferation of new churches, competition among them is rife and each thus makes effort to carve out a niche that it will service through a welldefined or streamlined set of products. ${ }^{10}$ These are just a few examples of religio-cultural factors that prosperity gospel thrives on.

\section{b. Socio-economic factors}

The religio-cultural factors discussed above, combined with socio-economic factors, make prosperity gospel appealing to many African people. Dan Lioy's (2007) remark illuminates the point when he says: “These health-andwealth mantras play right into 'traditional African values', which tend to 'link material success and spiritual success'” (2007: 47). At this point it might be relevant to remember the SA Reconciliation Barometer Survey 2013 Report that says after nearly twenty years of freedom in South Africa, "the top three

10 He gives examples of a church founded by Helen Ukpabio, a confessed former witch, specialising in delivering people who are under the possession of witchcraft spirit and Mountain of Fire and Miracles specialising in casting out demons of all specifications (2002:15) 
institutions as far as citizen confidence in 2013 is concerned, are religious institutions (67\%), the Public Protector (64.4\%) and the Constitutional Court (59.3\%). The three institutions with the lowest ratings are political parties (46.2\%), the police (47.9\%) and local government (48.6\%) (2013:19). ${ }^{11}$ This article argues that the rating of religious institutions as number one for citizen confidence has implications for the increase of membership in the prosperity gospel churches. "Africa is home to the world's poorest people" (Togarasei 2011:1). In an article investigating Pentecostalist attitudes towards consumption in Ghana, Meyer (1998) argues that economic decline was paralleled by the rise of the so-called Spiritual churches, which promised their members not only salvation but also material well-being in this world. They became increasingly appealing to mission church members after Independence in 1958. From the 1980s onwards (a period Mugambi describes as characterised by cries of despair all over the continent), Pentecostalist churches became increasingly popular (1998:759). As the SA Reconciliation Barometer Survey indicates, South Africans are likely to say the social relations of the country have improved, but this is not necessarily the case with regard to employment, income inequality and the economy in general. Actually, in 2013 the gap between the rich and the poor has widened (36.7\%) rather than narrowed (30.3\%) (Wale 2013:14). Overwhelmed by the United Nations statistics on African poverty Togarasei perceives the thriving of Pentecostal gospel of prosperity in a context of poverty indeed paradoxical (2011:341). Two examples might illuminate the paradoxical circumstance perceived by Togarasei. The following quotations are made by Cotterell (1993) referring to two prosperity gospel leaders, Ray McCauley and Gloria Copeland respectively:

"I want to get to the place where I can give away $90 \%$ of my income. We've had countless testimonies of people who have started tithing or increased their giving. God has prospered them in so many ways" (McCauley, in Cotterell 1993:6).

You can give $\$ 1$ for the Gospel's sake and $\$ 100$ belongs to you; give $\$ 10$ and receive $\$ 1000$; give $\$ 1000$ and receive $\$ 100,000$. I know that you can multiply, but I want you to see it as black and white and see

11 The same can be said of Mugambi's portrayal of the conditions of other African states in more or less than twenty years after independence above. 
how tremendous the hundredfold return is... Give one house and receive one hundred houses or one house worth one hundred times as much. Give one airplane and receive one hundred times the value of the airplane. Give one car and the return would furnish you a lifetime of cars. In short, Mk. 10:30 is a very good deal (Copeland, in Cotterell 1993:17).

"This, however, does not mean that everyone in these churches is rich. There are some poor people but usually these are those people who feel they are on a journey to prosperity and those who aspire to be rich, who are then encouraged by the doctrine of prosperity preached in these churches" (Togarasei 2011: 340-341). However, a promise of material and spiritual blessings, even if it means giving generously to the religious leader, for some of those who have been severely ravaged by poverty, might be worth a try.

It is important to note however that prosperity gospel is not only attractive to the poor but also to the rich. According to Togarasei (2011), "the teaching on prosperity has made the rich to feel at home. They found it to be a departure from the missionary teaching that pronounced blessings on the poor" (2011:340). Some join to secure their businesses. ${ }^{12}$ In the same article, Meyer (1998) also sheds light on the attitudes towards the market. She attests to being successful in life as one of the great concerns of the members of Pentecostalist churches. She substantiates by stating that in the face of inflation and economic decline, Pentecostalists seek divine protection to carry on and progress. They take great care not to fall victim to witches who are motivated by envy and seek to do away with successful traders or to prevent business from ever prospering. Moreover, some traders use magical powers to prosper while others who sell the very same items do not prosper. When they are rich they might forget the requirements of the power resulting in the magical power turning against them. By offering prayers for the progress of business, Pentecostalism provides assistance which is in many respects complementary to popular trade magic while not involving a pact with a destructive power and thereby rendering itself

12 Corroborating this statement, Meyer refers to a 'National Deliverance Meeting' organized by The Lord's Pentecostal Church in April 1992 in its 'healing station' at Tokokoe, where most of the persons attending were traders seeking success in business (1998:762). 
attractive to traders (1998:762-764). "In contrast to the mission churches, which discard such ideas as superstitions and propagate a secular view of the market, Pentecostalist churches take the widespread fear of the market as a magical place as a point of departure, thereby engaging actively in the enchantment of the economy" (Meyer 1998:374). Last but not least is Pentecostalism's global outlook which is attractive to some rich people who are keen to use the movement's international connections to import goods and resell them at a profit (Maxwell 1998:362).

Finally, Pentecostalism also provides home to those who feel marginalised in gerontocratic and patriarchal societies (Meyer 1998:759, 2004: 460). Maxwell notes that besides healing, security is also a main concern, for example fertility, success in public examinations, jobs, and repaired marriages are some of the concerns (1998:366). These are mainly the concerns of youth and women who are likely to feel uneasy under gerontocracy and patriarchy respectively. Echoing the same sentiment, Meyer (1998) avers that:

Socially speaking, the churches are most attractive to people who are relatively powerless in the male-oriented gerontocratic power structure which still prevails in Ewe society, and who attempt to move upward economically, mainly by business and trade (Meyer 1998:759).

While she speaks specifically about the Ewe society of Ghana, this can be said of other African societies as well. She argues that, while in most cases the immediate reason for a person to join a Pentecostalist church is an experience of affliction, the experience of healing as such cannot account for continued church membership. Rather, in these churches people find a perspective from which to look at the changing world (1998:759).

\section{Should contextual reading take responsibility?}

The article reasons that prosperity gospel exploits poor people. The claim of having a solution to social and economic problems tends to get the attention of the people (Gbote 2013:56). This article agrees with Meyer (1998) that prosperity churches cannot offer efficient remedies against economic misery on a large scale and most members definitely are not rich. Rather, they provide an imaginary space in which people may address their 
longing for a modern, individual and prosperous way of life (1998:763). What the article identifies in the "ministry" of prosperity gospel is that it utilises the African context to further exploitative selfish ends, for the donations definitely improve the leaders' financial conditions. At a very superficial level, it reads the Bible to capitalise on the plight of the poor and the socially and otherwise marginalised people. Describing the legalistic approach of prosperity gospel to suffering, Cotterell (1993) avers that:

The various "laws" proposed by this school of prosperity theology are such that prosperity in any or all of these realms is in direct proportion to an individual's faithfulness to God (and especially to the Scriptures). This basic principle is then assumed to operate with something like mathematical precision. The resultant prosperity is then regarded as the best and clearest testimony to the consistency of that Christian's faithfulness to God (1993:7).

However, he earlier predicted the consequences of such an approach:

When the law doesn't work the Christian may well feel that it is his lack of dedication to God that is at the root of the problem. Since we are all of us perennially aware of our inadequacy, the search for more spirituality, longer quiet times, more earnest prayer, more giving to good causes begins. That way leads to discouragement and even disaster (1993:6).

What is reckoned viable in this article in an attempt to improve the situation of the poor is an engagement with the social structures. Equitable distribution of resources needs to be emphasized as an imperative from God.

The question to be asked is should contextual reading take responsibility for such an interpretation of the Bible. The article fails to categorise prosperity gospel as African contextual theology although African contextual circumstances feature in their ministry. The reason for this uncertainty is that the loyalty of prosperity gospel is not with the African culture that it exploits. Its loyalty is global. Quoting Gifford, Robbins (2004) describes prosperity gospel as "often most indigenous when inveighing against the local most strongly" (2004:129). Quoting Casanova he says, "it is in their very struggle against local culture that they prove how locally rooted they are" (2004:129).The bad economic conditions of the African continent have 
destroyed hope of improvement for some people in Africa. The desperation they find themselves in has rendered them vulnerable to any promise of betterment without scrutinising it. By invoking some of the African worldview sentiments, prosperity gospel priests prey on the vulnerable. Just an imaginary space where they can express their plight suffices. For those who find an opportunity to do business internationally it is a twoway situation. In that case the prosperity priests still benefit. It is to be seen whether this situation can continue forever.

\section{Conclusion}

The article looked at the reading of the Bible in the African context. It identified two currents of Bible reading in Africa. The first one emphasises the context of the Bible and its author while the other emphasises the context of the reader. These currents are institutional reading and popular reading. The article then proceeded to examine the popularity of prosperity gospel in Africa. It concludes that prosperity gospel takes advantage of the religio-cultural and socio-economic contexts in Africa. Particularly, it is the socio-economic conditions that render the people vulnerable and the religio-cultural factors ease the way for prosperity gospel. The article therefore reasons that the relationship between prosperity gospel and the African people is not love but infatuation.

\section{Bibliography}

Adamo, DT 2011. Christianity and the African traditional religion(s): The postcolonial round of engagement in Verbum et Ecclesia 32(1), pp 1-10. http://www.ve.org.za/index.php/VE/article/viewFile/285/663

[Accessed: 23/01/2015]

Anderson, AH 2001. African Reformation: African Initiated Christianity in the 20th Century. Trenton, NJ: Africa World Press. 
Asamoah-Gyadu, JK. 2005. Born of Water and the Spirit: Pentecostal/ Charismatic Christianity in Africa in African Christianity: An African Story. Perspectives on Christianity Series. Series 5, Volume 3. (Series Editors Kalu OU; Hofmeyr, JW; Maritz, PJ) Sunnyside: Business Print Centre. pp 388-409. [Online] http://repository.up.ac.za/bitstream/ handle/2263/21579/016_Chapter15_p388409.pdf?sequence=17 [Accessed: 23/01/2015]

Asamoah-Gyadu, JK 2012. "From Prophetism to Pentecostalism”: In Religious Innovation in Africa and African Religious Scholarship in African Traditions in the Study of Religion (Eds Adogame, F, Chitando, E \& Bateye, B). Farnham: Ashgate Publishing Limited. pp 161-173.

Bosman, H 2015. The Hebrew Bible / Old Testament Studies in Africa. In Hebrew Bible / Old Testament. Volume III: From Modernism to Post-Modernism. Part II: The Twentieth Century - From Modernism to Post-Modernism (Ed. Magne Sæbo). Göttingen: Vandenhoeck \& Ruprecht GmbH \& Co. KG. pp 253-266.

Clarke, CR 2013. Pan-Africanism and Pentecostalism in Africa: Strange Bedfellows or Perfect Partners? A Pentecostal Assist towards a Pan-African Political Theology. Black Theology, vol. 11, no. 2, pp 152-184. [Online] http://web.ebscohost.com.ez.sun.ac.za/ ehost/detail/ detail?vid=2\&sid=de1173a7-b53f4421bf3bb2e39bc373c4\%40sessionmgr 4005\&hid= 4212\&bdata=JnNpdGU9ZWhvc3QtbGI2ZSZzY29wZT1zaXRI\#db=aph\&AN=89984281 [Accessed: 23/01/2015]

Cotterell, P 1993. Prosperity Theology. Leicester: Religious and Theological Studies Fellowship. [Online] http://www.biblicalstudies.org.uk/ pdf/rtsf/prosperity_cotterell.pdf [Accessed: 13/04/2015]

Duncan, G \& Kalu, OU. 2005. Bakuzufu: Revival Movements and Indigenous Appropriation in African Christianity in African Christianity: An African Story. Perspectives on Christianity Series. Series 5, Volume 3. (Series Editors: Kalu OU; Hofmeyr, JW, Maritz, PJ) Sunnyside: Business Print Centre. pp 278-308. [Online] http://repository. up.ac.za/bitstream/handle/2263/21579/012_Chapter11_p278-308.pdf?sequence=13 [Accessed: 23/01/2015] 
Field, MJ 1940. Some New Shrines of the Gold Coast and Their Significance. Africa: Journal of the International African Institute, Vol. 13, No. 2, pp 138-149. [Online] http://www.jstor.org.ez.sun.ac.za/stable/ pdf/1156954.pdf?acceptTC=true\&jpdConfirm=true [Accessed: 23/01/2015]

Ganiel, G 2006. Race, Religion and Identity in South Africa: A Case Study of a Charismatic Congregation in Nationalism and Ethnic Politics, 12:3-4. pp 555-576. [Online] http://www.tandfonline.com/doi/ pdf/10.1080/13537110600882858 [Accessed: 23/01/2015]

Gbote, EZM \& Kgatla, ST 2014. Prosperity gospel: A Missiological Assessment. HTS Teologiese Studies/Theological Studies 70(1), Art. \#2105, 10 pages. [Online] http:// dx.doi.org/10.4102/hts.v70i1.2105 [Accessed: $23 / 01 / 2015]$

Gbote, EZM 2014. Commercialized Gospel: A Missiological Assessment of Prosperity Gospel. Unpublished Thesis. University of Pretoria: Pretoria. [Online] http://repository.up.ac.za/bitstream/handle/2263/40347/Gbotoe_ Commercialized_2013.pdf?sequence=2 [Accessed: 23/01/2015]

Hofmeyr, JW 2005. Mainline Churches in the Public Space, 1975-2000. African Christianity: An African Story. Perspectives on Christianity Series. Series 5, Volume 3. (Series Editors, Kalu, OU, Hofmeyr, JW, Maritz, PJ) Sunnyside: Business Print Centre. pp 361-387. [Online] http://repository.up.ac.za/bitstream/handle/2263/21579/015_Chapter14_p361-387.pdf? sequence $=16$ [Accessed: 23/01/2015]

Holter, K 2008. Whose book is it, by the way? An aspect of popular and scholarly strategies for interpreting the Bible in Africa. Mission to the World: Communicating the Gospel in the 21 ${ }^{\text {st }}$ Century: Essays in Honour of Knud Jørgensen (Eds Engelsviken, T, Harbakk, E, Rolf, Olsen \& Thor, Strandenæs) Oxford: Regnum. pp 205-214. [Online] https://books.google.co.za/books?id=CkRCPdHtluMC\&pg=PA9\&dq=Mission+to+the+W orld:+Communicating+the+Gospel+in+the +21 st+Century: + Essays + in + Honour+of $+K$ nud $+\mathrm{J} \%$ C3\%B8rgensen\&hl=en\&sa $=X \& \mathrm{X}==$ VEvVdiYMcffaszYgbgJ\&ved $=0$ CBsQ6AEwAA $\# \mathrm{v}=$ onepage $\mathrm{q}=$ Mission\%20to\%20the\%20World\%3A\%20Communicating\%20the $\% 20$ Gospel\%20in\%20the\%2021st\%20Century\%3A\%20Essays\%20in\%20Honour\%20of\%20 Knud\%20J\%C3\%B8rgensen\&f=false [Accessed: 23/01/2015] 
Holter, K 2009. Does a Dialogue between Africa and Europe Make Sense. African and European Readers of the Bible in Dialogue (Eds, De Wit, H \& West, GO). Pietermaritzburg: Cluster Publications. pp 69-80.

Holter, K 2011. Historical-critical Methodology in Old Testament Essays 24/2, pp 377-389.

Kimilike, LP 2006. An African Perspective on Poverty Proverbs in the Book of Proverbs: An Analysis for Transformational Possibilities. Unpublished Dissertation. Pretoria; University of South Africa.

Koch, B. 2009. The Prosperity Gospel and Economic Prosperity: Race, Class, Giving, and Voting. Unpublished Dissertation. Indiana University. [Online] https://philanthropy.iupui.edu/files/file/brad_koch_final_ dissertation.pdf [Accessed: 04/01/2016]

Koch, BA 2014. Who Are the Prosperity Gospel Adherents? Journal of Ideology: A Critique of Conventional Wisdom, Volume 36. [Online] http://www.Isus.edu/Documents/Offices\%20and\%20Services/Community0utreach/ JournalOfldeology/who\%20are\%20the\%20prosperity\%20gospel\%20adherents\%20 by\%20bradley\%20a\%20koch.pdf [Accessed: 04/01/2016]

Le Roux, JH 1993. A Story of Two Ways: Thirty Years of Old Testament Scholarship in South Africa. Pretoria: Verba Vitae.

Lioy, D 2007. The Heart of the Prosperity Gospel: Self or the Savior? Conspectus 4:1, pp 41-64. [Online] http://reference.sabinet.co.za.ez.sun.ac.za/ webx/access/electronic_journals/conspec/conspec_v4_a3.pdf [Accessed: 23/01/2015]

Manganyi, JS \& Buitendag, J 2013. A critical analysis on African Traditional Religion and the Trinity. HTS Teologiese Studies/ Theological Studies, 69(1), Art. \#1934. [Online] http://dx.doi.org/10.4102/hts. v69i1.1934

Masenya, M \& Ramantswana, H 2012. Anything New under the Sun of South African Old Testament Scholarship? African Qoheleths' Review of OTE 1994-2010. Old Testament Essays 25(3), 598-637. 
Maxwell, D 1998. Delivered from the Spirit of Poverty? Pentecostalism, Prosperity and Modernity in Zimbabwe. Journal of Religion in Africa, Vol. 28, Fasc. 3, pp 350-373. [Online] http://www.jstor.org/stable/1581574 [Accessed: 23/01/2015]

Meyer, B 1998. Commodities and the Power of Prayer: Pentecostalist Attitudes towards Consumption. Contemporary Ghana Development and Change, Vol. 29, pp 751-776. [Online] http://web.b.ebscohost.com. ez.sun.ac.za/ehost/pdfviewer/pdfviewer?vid=2\&sid=627b1408-9b52-4a76-bc48fe50cb92e96f\%40sessionmgr112\&hid=124 [Accessed: 23/01/2015]

Meyer, B 2004. Christianity in Africa: From African Independent to Pentecostal-Charismatic Churches. Annual Review of Anthropology, Vol. 33, pp 447-474. [Online] http://www.jstor.org/stable/25064861 [Accessed: 23/01/2015]

Mojola, AO 2014. The Old Testament or Hebrew Bible in Africa:

Challenges and Prospects for interpretation and translation. Verbum et Ecclesia, 35(3), Art. \#1307, 7 pages. [Online] http://dx.doi. org/10.4102/ ve.v35i3.1307 [Accessed: 23/01/2015.

Mugambi, JNK 2003. Christian Theology and Social Reconstruction. Nairobi: Acton.

Mugambi, JNK 2005. Christianity and the African Cultural Heritage. African Christianity: An African Story. Perspectives on Christianity Series. Series 5, Volume 3. (Series Editors, Kalu OU; Hofmeyr, JW, Maritz, PJ) Sunnyside: Business Print Centre. pp 517-542. [Online] http://repository.up.ac.za/bitstream/handle/2263/21579/021_Chapter20_p516-542.pdf? sequence $=25$ [Accessed: 23/01/2015]

Ngong, DT 2009. Salvation and Materialism. African Theology in Studies in World Christianity. Volume 15, Issue 1, pp 1-21. [Online] http://dx.doi. org/10.3366/ E135499010900032X [Accessed: 23/01/2015]

Nyende, P 2007. Institutional and Popular Interpretations of the Bible in Africa: Towards an Intergration. The Expository Times, Volume 119 Number 2, pp 59-66. [Online] http://ext.sagepub.com.ez.sun.ac.za/ content/119/2/59.full.pdf+html [Accessed: 23/01/2015] 
Robbins, J 2004. The Globalization of Pentecostal and Charismatic Christianity. Annual Review of Anthropology, Vol. 33, pp 117-143. [Online] http://content.ebscohost.com.ez.sun.ac.za/ContentServer.asp?T=P\&P=AN\&K $=15309620 \& S=R \& D=a p h \& E b s c o$ Content $=d G J y M N L e 80 S$ ep7Q4v\%2Bbw0LCmr02eprBSsq m4SrSWxWXS\&ContentCustomer=dGJyMPGqsEq0rrVPuePfgeyx44Dt6fIA [Accessed: 23/01/2015]

Togarasei, L 2011. The Pentecostal Gospel of Prosperity in African Contexts of Poverty: An Appraisal. Exchange 40, pp 336-350.

Ukah, A 2007. African Christianities: Features, Promises and Problems. [Online] http://www.ifeas.uni-mainz.de/Dateien/AP79.pdf [Accessed: 23/01/2015]

Ukpong, JS 2000. Developments in Biblical Interpretation in Africa: Historical and hermeneutical directions. Journal of Theology for Southern Africa, 108, pp 3-18. [Online] http://web.ebscohost.com.ez.sun. ac.za/ehost/detail/detail?vid=2\&sid=77e869cf-de16-4365-a7b8-cd702b331edd\%40sessi onmgr4004\&hid $=4212 \&$ data $=$ JnNpdGU9ZWhvc 3QtbGI2ZSZzY29wZT1zaXRI\#db=rfh\&A $\mathrm{N}=$ ATLA0000006734 [Accessed: 23/01/2015.

Ukpong, JS 2001. New Testament Hermeneutics in Africa: Challenges and Possibilities. Neotestamentica 35(1-2), pp 147-167. http://reference.sabinet. co.za.ez.sun.ac.za/webx /access/ electronic_journals/neotest/neotest_v35_n1_a10.pdf [Accessed: 20/02/2015]

Wale, K 2013. Confronting Exclusion: Time for Radical Reconciliation. SA Reconciliation Barometer Survey: 2013 Report. [Online] http:// reconciliationbarometer.org/wp-content/uploads/2013/12/JJR-Barometer-Report-201322Nov1635.pdf [Accessed: 23/01/2015] 